\title{
Performance Appraisal Systems In Public Sector Universities Of Pakistan
}

\author{
Ambreen Anjum \\ Department of Applied Psychology, The Islamia University of Bahawalpur, Pakistan \\ E-mail: aambreenaanjum@hotmail.com
}

Kausar Yasmeen (Corresponding author)

Department of Economics, The Islamia University of Bahawalpur, Pakistan

Tel: +92 300899 5083, Email: eco.yasmeen@ gmail.com

Bashir Khan

Assistant Director Statistical Information Unit

Higher Education Commission

Tel: +92 333534 8463, Email: bkhan@hec.gov.pk

Received: July 17, 2011 Accepted: August 01, $2011 \quad$ DOI: 10.5296/ijhrs.v1i1.851

\begin{abstract}
The current research investigates different aspects of performance appraisal system, \& how performance appraisal system can play its role in improving the performance of teachers in higher education institutions of Pakistan. In the present study multi- methods approach was used which consist of survey questionnaire and in depth interviews. Survey questionnaire was used in order to investigate various aspects of current performance appraisal system and in depth interview to study the perception of teachers on performance appraisal approach. The focus of the study was on the employees of Bahauddin Zakariya University (BZU) Multan, Pakistan. The researchers undertook the public sector University of Pakistan, as a case study in the present study. Results show that although employees of BZU are aware of the useful outcomes of performance appraisal but there are some hindering factors e.g. untrained raters, exclusion of multiple raters, absence of feedback in the way of successful implementation of performance appraisal system. Present study also suggests the solutions with their implications regarding said factors.
\end{abstract}

Keywords: Performance appraisal (PA), effectiveness, procedure, higher educational institutes. 


\section{Introduction}

Effective performance management of professionals in academic institutions has particular significance; it determines the institution's success or failure. Davis (1995) says Performance management is a joint process that involves both the supervisor and the employee, who identify common goals, which associate to the higher objectives of the institution.

Talking about the nature of the performance appraisal Wilson (2005) says it is neither a technique nor a single step, it can be considered a continues process that includes employee motivation to perform well, knowledge of employees about what their managers expect of them and evaluation of their performance aimed at identifying areas where the improvements are needed.

Longenecker (1999) argued that there are several reasons, why an organization needs a comprehensive performance appraisal system; it is needed to take accurate decisions regarding promotions, demotions, pay packages and transfers. Mullins (1996) adds that comprehensive appraisal is employed to decide Pay, allocation of duties, responsibilities, promotions and training needs of employees. Performance appraisal system not only helps employees to identify his or her strengths and weaknesses but it also helps directors in timely predictions and taking actions promptly to uncertain changes.

According to Armstrong (2001) accuracy and fairness in the use of appraisal system is one of the key issues. Various practices e.g. annual confident report (ACR), Management by objectives (MBO) etc has been used to evaluate the employees. In 1970s performance appraised system (PA) was introduced. A new variant of performance appraisal is 360 degree performance appraisal. One important aspect of this new variant was use of multiple raters. Wisc (1998) says in 360 degree performance appraisal several sources e.g. subordinates, supervisor (s) co-workers, dealers etc provide feedback on performance for each target rates. According to studies subordinate and co-worker ratings are particularly valuable because it provide different and significant perspectives on rates skill and behavior. Dalton (1996) stressed that it also informs people about the effect of their action on others in the work place. Rothstein (1990) concludes that rating by multiple raters provide adequate assessment of performance.

According to the studies another important factor in determining effectiveness of performance appraisal system is the acceptance of its users. Roberts (2003) emphasized that employees must have trust on the accuracy and fairness of performance appraisal system, otherwise they are tremendous waste of time and money spend on implementation and development. According to Roberts (2003) Employee participation in all aspects of appraisal process is a key element of intrinsic motivational strategies that facilitate workers' development \& growth. Employee participation gives opportunity to interject their voice. Moreover, it generates an atmosphere of co-operation \& trust which reduces defensive behavior and rater-rate conflict.

Numerous studies (e.g. Rudner, 1992) emphasize that appraiser must be trained in order to 
familiarize with the measure they will work with process of implementation and interpret the data. Harris (1988) advocates Runder that organization should provide training on regular basis. Researches also emphasize the training of ratee because they must understand the standards that are used to measure their performance.

Another major factor that increases effectiveness of performance appraisal system is to give feed back to employee regarding their performance. Performance feedback not only generates change in job behavior but also improves ratee organizational commitment (Tziner \& Kopelaman, 2002). Timely performance feedback provides the opportunity to employee to discuss their problems and support which they require in order to meet expected outcomes.

\section{Context of the study}

Pakistan is a developing country which got its independence in August of 1947. The general state of education in Pakistan at the time of independence was very poor and this impacted negatively not only on the manpower requirements and economy but also on the social and cultural development of the country. At the time of independence, the country had only one intuition of higher education, the University of Punjab. Over the next 20 years, several higher education institutions were established to help fuel the country's socio-economic development. The government of Pakistan established university grant commission (UGC) in 1974 by an act of parliament for maintaining standards of education and uniform policy aimed at bringing about national unity and cohesion. In 2001 UGC was introduced with the name of Higher education commission Pakistan.

Higher education commission (HEC) of Pakistan is carrying out a variety of programs for improving teachers learning and development e.g. training programs improved facilities, scholarships opportunities and revising compensation packages etc so after spending lot of funds on Teachers, HEC require perfection in their profession and loyal and sincerity with institution in return. Secondly many new recruits are joining the service in number of new and old established institutions and therefore head teachers needed a mechanism of controlling and disciplining them. So for this very purpose HEC evaluates the performance of Teachers through performance appraisal. Performance appraisal can provide the basis for key managerial decisions such as those related to the allocation of duties \& responsibilities, Promotion, pay, training and development needs and terminations.

\section{Objectives of the Study}

The main of the study was to analyze PA system currently used in BZU and appraisal practice for teachers of this university. The specific objectives are:

1. To explore the main purpose of performance appraisal in higher educational institutions of Pakistan.

2. To analyze the significance of the performance review discussion, and feedback in evaluating teachers performance.

3. To investigate factors that contributes to effective performance appraisal system. 


\section{Macrothink}

International Journal of Human Resource Studies

ISSN 2162-3058

2011, Vol. 1, No. 1

4. To explore employees' perceptions about the outcomes of performance appraisal.

5. To discuss problems which are being faced by faculty regarding performance appraisal in BZU

6. . To propose the recommendations with their implication.

\section{Demographic Characteristics of respondents}

The sample contained 70 employees currently working at BZU Multan. Stratified sampling method was used in this study. Three Strata were decided as faculty, chairman and Dean. Respondents teaching experience is presented in table 1.

Table 1: Distribution of respondents by teaching experience

\begin{tabular}{|l|l|l|}
\hline Teaching experience(years) & Frequency & Percentage \\
\hline 2 years or less & 20 & 28.57 \\
\hline 3 to 5 & 30 & 42.85 \\
\hline 6 to 9 & 10 & 14.28 \\
\hline $10-20$ & 10 & 14.28 \\
\hline
\end{tabular}

\section{Research Methodology}

Data for present study was collected by the use of survey questionnaire and in depth interviews. The use of multi methods in a research secures in depth understanding of the Phenomenon in question as it adds vigor, breadth and depth to the investigation (cresswell, 1994). The quantitative approach was used to get the various aspects of current performance appraisal system and qualitative approach was used to study employees' perception regarding performance appraisal system. In order to ensured to increase reliability researcher decided to conduct in depth interviews from 20 interviewees belonging to all three strata explained previously. Researcher tape-recorded all interviews and field notes were prepared in order to verify the data collected during interviews. Researchers analyzed 70 questionnaires.

\section{Data analysis, Research Findings and Discussion.}

\subsection{The main purpose of performance appraisal in BZU.}

According to the tool used in the present research the researcher identified $64 \%$ of respondents approved that performance appraisal is used for promotion as one faculty member said that

"The appraisal of employee is only reviewed at the time of selection broad conducted in university for target employee promotion"

However, one head of the department claimed that" On the base of evaluation employees are 
awarded with annual increment, he also said that training \& and work shops are conducted to enhance the learning \& performance of Teachers"

Majority of teachers believe that performance appraisal in BZU is used only for promotion purpose. This is the major shortcoming of currently using system and need is to fill the gap as according to the previous studies purpose of performance appraisal is to identify the training needs, promotions, important decisions, salary and open and timely discussions regarding employee performance

What is the purpose of performance appraisal in BZU?

\begin{tabular}{|l|c|}
\hline Purpose & Percentage \\
\hline Regular and timely feedback & $5 \%$ \\
\hline Training needs & $5 \%$ \\
\hline Salary & $14 \%$ \\
\hline Promotion & $64 \%$ \\
\hline Review-discussion & $6 \%$ \\
\hline Others & $6 \%$ \\
\hline
\end{tabular}

\subsection{Employee Participation}

According to the Cox (2000) systems that are implemented with meaningful consultation of employees are more effective then those which are implemented unilaterally by supervisor. According to the result of present study the case of BZU is not very much satisfactory. As $85 \%$ of respondents disagreed with the statement "Are you allowed to participate in the planning of performance appraisal".

According to the literature employee participation enhance motivation, feelings of fairness and acceptance of performance appraisal system. Thus to gain these positive effects it must be realized that employee participation is an enriching factor.

\subsection{Rater-ratee Training}

Training of both rater and ratee is one of the most significant procedures that facilitate effective appraisal system. The empirical findings show that this is one of the most critical 
short coming of the current Performance appraisal used in BZU. For instance, when researcher inquired whether they received any training, $79 \%$ of the respondents pointed out that they received no training while only $21 \%$ said they received training. Furthermore, when researcher asked whether they think all those individuals who are to be involved in the whole appraisal process should receive adequate training? The $72 \%$ of respondents agreed only $28 \% \%$ disagreed. As during an interview an assistant professor said that.

"I have been appraised number of times but I have never been trained on what appraisal is all about. My understanding regarding that appraisal system is not adequate"

One chairman said,

"Although university never arranges such type of trainings but people on administrative posts have knowledge regarding this system."

However, he admitted that training facilitate the effectiveness of the appraisal process.

In short, with the adequate knowledge from training, the appraisal process may not only be implemented more effectively but will also help minimizing some of the major problems inherent in appraisal system e.g. teachers' resistance. The planners of the current appraisal in BZU and those in the internal arena had realized the need of training for both appraisers and appraises.

\subsection{Evaluation standards}

Worker must have clear knowledge about their job. They should know what they have to perform in order to fulfill their job target in an institution. The developed performance elements describe what the employees really have to perform and the performance standards guide the workers that how effectively they must have to perform. However, the research conducted in BZU has shown different results as only $35 \%$ of the respondents are of the view that they are aware of the standard used to evaluate their performance. Here comes divergence of opinion amongst the head of the department and teachers as one head of the department said in this interview.

'There are clear objectives and standards to evaluate employee performance and these standards are considered while making any judgment about the employee"

Result of the present research shows that there is immense need of detailed evaluation system with clear evaluating standards for employees. Furthermore, teachers should guide regarding their goals and job description through training and workshops.

\subsection{Feedback and performance review discussions}

Providing prompt and constructive feedback in the appraisal process plays a very crucial role for professional growth of an employee. Although Harris (1988) says this is the manner in which employees receive feedback on their performance a key factor in determining the success of the performance appraisal system. Because hearing information about the self discrepant from one's self image is always difficult and painful. Davis and Landa (1999) emphasize that regular communication in informal and confidential environment play a 
significant role in the professional development of the employees. The result of present research show that this is another major shortcoming of the performance management system of BZU, as $75 \%$ disagree with the statement "Do you receive timely and regular performance feedback? Similarly $78 \%$ of respondents said that head of the department does not discuss their assessment. For instance a senior teacher said that

"The confidentiality of appraisal system is not appropriate and why should it be confidential if you have recorded something that is true about the employee. Confidentiality makes employee lose confidence and trust in chairman, including the appraisal system itself".

Because in BZU appraise is not allowed to view that comments. Employees as the recipients of the appraisal process have shown displeasure on this confidentiality.

According to the literature e.g. Taylor (1998) appraisal system not only should be open but it should also leave room for discussion. Performance review discussions help in the professional development of employee and successful implementation of appraisal system.

Do you receive regular performance feedback?

\begin{tabular}{|l|l|}
\hline Response & Percentage \\
\hline Yes & $25 \%$ \\
\hline No & $75 \%$ \\
\hline
\end{tabular}

\subsection{Factors contributing to an effective performance appraisal.}

For the transparency of appraisal system it is very effective to use the multiple sources of evaluation for each target ratee. But the case of BZU is different. Current study shows $60 \%$ of the teachers disagreed with the statement is the opinion of co-workers and students considered in performance appraisal? Additionally an assistant professor said that

"Chairman is all in all to evaluate teachers. He evaluates according to his own wishes" Following question was that "what is the most important factor for effective performance appraisal?' $70 \%$ of the employee said evaluation from multiple raters is the most important factor in the effective performance appraisal.

So use of multiple sources for evaluation, adequate training of rater and ratee, adequate feed back and review discussion play important role in the successful implementation of appraisal system. 
What is the most important factor for effective performance appraisal?

\begin{tabular}{|l|l|}
\hline Factors & percentage \\
\hline Feedback & $5 \%$ \\
\hline Review discussion & $5 \%$ \\
\hline Rater-ratee participation & $20 \%$ \\
\hline Multiple sources for evaluation & $70 \%$ \\
\hline
\end{tabular}

\subsection{Impact of Performance Appraisal on Employees' Performance}

Results of the present study have shown that $85 \%$ of the respondents agreed with the statement that performance appraisal has an impact on performance whereas only $15 \%$ of respondent disagreed with the statement. Similarly a teacher said,

"Performance appraisal should use regularly. In this way employee get the chance to improve performance. Another positive aspect of performance appraisal is the recognition of employee achievements"

So results of present study have clearly shown that majority of teachers of BZU have strong wish for fair and systematic performance appraisal. In short on the basis of these finding it seems important for each educational institution to regularly check if their performance appraisal is perceived as intended and if appraises still support system and process.

Indication: whether the performance appraisal has an effect on effective job performance.

\begin{tabular}{|l|l|}
\hline Response & Percentage \\
\hline Yes & $85 \%$ \\
\hline No & $15 \%$ \\
\hline
\end{tabular}

\section{Summary of the Key Findings}

1. It has been found that the appraisal system does not address the important purpose upon which it should. It is used only for promotion purpose and salary increase.

2. Multiple raters system is not used. 
3. Review discussions are not conducted in BZU.

4. Teachers are not allowed to participate in the planning process of appraisal system.

5. Teachers are in favor of the use of performance appraisal. But they have strong desire of transparent and systematic performance appraisal.

\section{Recommendations}

On the basic of the findings of this study, researchers recommended that following measures are crucial for developing and implementing effective performance appraisal for teachers of higher educational institutions of developing countries like Pakistan.

1. Performance appraisal should not only be conducted to take promotion decisions for teachers, rather it should be able to guide the institution identifying teachers, training needs, their execution and evaluation on whether they accomplish their intended objective.

2. During the design of performance appraisal in educational institutions, the management should consider all aspects of an effective system so as to reach the goals upon which they are designed. The major factors are: Ratee participation in planning process of performance appraisal, employee performance review, provide feedback to employee, multiple raters and the procedure for system should be ratable.

3. For Raters training should be provided. The trainings can be done through institution-based workshops. Which are contextual, less expensive, easy to arrange and thus effective.

4. Teachers should have sufficient knowledge regarding the standards on which they are measured. It is observed that the role of immediate boss is important in this regard. They should not only guide in the professional life of teachers but also should maintain such a co-operative environment in which teachers can discuss their problems.

In short, performance appraisal is the only tangible metric by which an institution can check and manage the performance of its diverse employees.

In order to increase the credibility of performance appraisal system there should be participation and ownership by the employees. In addition, 360-degree appraisal, adequate training, procedural justice, goal-setting and performance Feedback are the most important factor in determining the success of appraisal system in any institution. 


\section{Macrothink}

\section{References}

Armstrong, M. (2001) Human Resource Management Practice, Kogan Page Publishers, 8th ed.

Cresswell, JW.(1994). Research design: qualitative and quantitative approaches. Thousad oasks:Sage.

Cox, A. (2000). The importance of employee participation in determining pay system effectiveness. International Journal of Management Reviews, 2 (4), 357-375.

Davis, R. (1995). Choosing performance management, holistic approach Journal, Cupa Publication, New Delhi- India.

Dalton, M. (1996). Multirater Feedback and Conditions for Change. Consulting Psychology Journal, 48 (1), 12-16.

Davis, T. \& Landa. M. (1999). A Contrary Look at performance Appraisal. Canadian Manager/Manager Canadian, Fall, 18-28.

Harris, C. (1988). A Comparison of Employee Attitude Toward Two Performance Appraisal Systems. Public Personnel Management, 17 (4), 443-456

Longenecker, CA. (1999). Creative Effective Performance Appraisals.

Ind. Manag, 18-23.

Mullins, LJ. (1996). Management and organizational behaviour. London:Pitman Publishing.

Rothstein, HR. (1990). Interrater Reliability of Job Performance Ratings: Growth to Asymptote level With Increasing Opportunity to Observe. Journal of Applied

Psychology, 75 (3), 322-327.

Rudner, LM.. (1994). Reducing Errors Due to the Use of Judges. Practical Assessment, Research \& Evaluation, 7 (26), 241-271.

Roberts, G. (2003). Employee Performance Appraisal System Participation.

A Technique that Works. Pub. Pers. Manag, 32 (1), 89-98.

Taylor, G.(1998). Effective appraisal skills. Pembury: David grant publishing.

Tziner, A. \& Kopelman, RE. (2002). Is there a Preferred Performance Rating Format? A

Non-psychometric Perspective. Applied Psychology: An International Review, 51

(3), 479-503.

Wisc, PG. (1998). Rating differences in Multi-Rater Feedback. Chicago, IL: International Personnel Management Association Assessment Council's Conference on Professional Personnel Assessment. 


\section{Macrothink}

International Journal of Human Resource Studies

ISSN 2162-3058

2011, Vol. 1, No. 1

Wilson, JP. (2005). Human Resource Development: 2nd edition. Kogan

Page. London. 